\title{
Students' Gender-Related Choices and Achievement in Physics
}

IVANA JUGOVIĆ ${ }^{1}$

$\approx$ The goal of the research was to explore the role of motivation, gender roles and stereotypes in the explanation of students' educational outcomes in a stereotypically male educational domain: physics. Eccles and colleagues' expectancy-value model was used as a theoretical framework for the research.

The research sample included 736 grammar school students from Zagreb, Croatia. The variables explored were expectancy of success, selfconcept of ability and subjective task values of physics, gender roles and stereotypes, and educational outcomes: academic achievement in physics, intention to choose physics at the high school leaving exam, and intention to choose a technical sciences university course.

The results showed that girls had a lower self-concept of ability and lower expectancies of success in physics compared to boys, in spite of their higher physics school grades. Hierarchical regression analyses showed that self-concept of physics ability was the strongest predictor of physics school grades, whereas the utility value of physics was the key predictor of educational intentions for both genders. Expectancy of success was one of the key predictors of girls' educational intentions, as well. Endorsement of a typically masculine gender role predicted girls' and boys' stronger intentions to choose a stereotypically male educational domain, whereas acceptance of the stereotype about the poorer talent of women in technical sciences occupations predicted girls' lower educational outcomes related to physics. The practical implication of the research is the need to create gender-sensitive intervention programmes aimed at deconstructing the gender stereotypes and traditional gender roles that restrain students from choosing gender-non-stereotypical careers.

Keywords: academic achievement, gender roles, gender stereotypes, vocational choice, physics 


\section{Spolno povezane izbire in dosežki učenk_cev pri fiziki}

IVANA JugOvić

$\propto$ Namen raziskave je bil raziskati vlogo motivacije, spolnih vlog in stereotipov pri pojasnjevanju izobraževalnih dosežkov učenk_cev na stereotipno moškem izobraževalnem področju, tj. pri fiziki. Za teoretični okvir raziskave smo uporabile_i pričakovano-vrednotni model po Eccles idr. $\mathrm{V}$ raziskovalni vzorec je bilo vključenih sedemsto šestintrideset osnovnošolk_cev iz Zagreba, Hrvaška. Preučevane spremenljivke so bile: pričakovanje uspeha, samopodoba o zmožnostih in subjektivne vrednote nalog v fiziki, spolne vloge in stereotipi ter izobraževalni dosežki: akademski dosežki v fiziki, namera za izbiro fizike na maturi in namera za izbiro univerzitetnega študija na tehniško-naravoslovnem področju.

Izsledki so pokazali, da imajo deklice nižjo samopodobo o zmožnostih in nižja pričakovanja glede uspeha pri fiziki v primerjavi z dečki, in to kljub njihovim višjim šolskim ocenam pri fiziki. Hierarhična regresijska analiza je pokazala, da je samopodoba o zmožnostih pri fiziki najmočnejši napovedovalec šolskih ocen pri fiziki, medtem ko je bila uporabna vrednost fizike glavni napovedovalec izobraževalnih namer za oba spola. Pričakovanje uspeha je bilo prav tako eden izmed glavnih napovedovalcev izobraževalnih namer deklic. Podpora tipičnih moških spolnih vlog je napovedovala močnejše namere deklic in dečkov, da izberejo stereotipno moško izobraževalno področje, medtem ko je sprejetje stereotipov o slabšem talentu žensk v poklicih na področju tehničnih ved napovedovalo slabše izobraževalne dosežke $\mathrm{v}$ povezavi s fiziko. Praktične implikacije raziskave kažejo na potrebo po spolno občutljivih interventnih programih, ki merijo na dekonstrukcijo spolnih stereotipov, in tradicionalnih spolnih vlog, ki odvračajo učenke_ce od izbire spolno nestereotipnih karier.

Ključne besede: izobraževalni dosežki, spolne vloge, spolni stereotipi, izobraževalne izbire, fizika 


\section{Introduction}

Girls and women are underrepresented in educational and career paths in the STEM (Science, Technology, Engineering and Mathematics) field in the EU and the US (European Commission, 2014; National Science Foundation, 2015), and similar trends are found in Croatia. In the 2016/2017 school year, for example, girls accounted for only $0.1 \%$ of enrolments in secondary vocational schools for naval architecture in Croatia, $2.4 \%$ in schools for mechanical engineering, $3.5 \%$ in schools for electrical engineering, and $29.1 \%$ in schools for civil engineering (unpublished data obtained from the Ministry of Science and Education, 2016). Furthermore, in 2014, women comprised $18.8 \%$ of graduates from higher education institutions in the field of engineering and engineering trades, $19.5 \%$ in computing, and $40.9 \%$ in architecture and building (Croatian Bureau of Statistics, 2015). This strong gender segregation in education and occupations reinforces gender stereotypes, contributes to the under-valuation of women's work and to lower incomes for women, and leads to skill shortages in certain domains of the labour market (Bettio \& Verashchagin; 2009; European Commission, 2014; Grimshaw \& Rubery, 2007).

Enrolment in technical sciences university courses in Croatia requires the choice of physics as an optional subject in the national high school leaving exam (the state matura exam). Only very good results in physics in the matura exam can enable enrolment in the most prestigious faculties or courses. However, girls are less motivated for physics in Croatia; they find it less useful and less interesting than boys in both primary and secondary schools (Jugović, 2010; Marušić, 2006). Similarly, in a UK study, boys reported enjoying their physics lessons more and found physics more interesting and useful than girls; it was also found that boys are more likely than girls to report that they are good at physics (Mujtaba \& Reiss, 2012). Furthermore, studies have shown that students perceive physics as a masculine school subject (Archer \& Freedman, 1989; Francis et al., 2017; Stewart, 1998). Given the gender gap in motivation and educational choices related to physics, as well as students' endorsement of gender stereotypes about physics, the goal of the present study was to explore the factors that contribute to gender differences in academic achievement and educational choices in this domain.

\section{The expectancy-value theory}

There are a number of factors that have been identified as key to explaining why young men and women differ in their academic achievement and 
educational choices in the STEM field. These include girls' weaker motivation for this educational field (Jacobs, Lanza, Osgood, Eccles, \& Wigfield, 2002; Lupart, Cannon, \& Telfer, 2004; Murphy \& Whitelegg, 2006); weaker social support for girls to pursue the STEM domain (Mujtaba \& Reiss, 2013; Tenenbaum \& Leaper, 2003); a lack of female scientists and engineers as role models for girls (Blickenstaff, 2005; Herrmann et al., 2016); stereotypes regarding STEM as a male domain (Davies, Spencer, Quinn, \& Gerhardstein, 2002; Francis et al., 2017; Steele, 1997); and a discrepancy between the feminine gender role and the masculine image of STEM (Breakwell, Vignoles, \& Robertson, 2003; Gonsalves, 2014). Although valuable, these explanations tend to approach gender differences in educational choices in a fragmented manner rather than interrelating possible explanatory factors. Eccles et al's (1983) expectancy-value theory of achievement motivation was chosen as a theoretical framework for this study because it is a social-psychological theory aimed specifically at explaining gender differences in educational achievement and choices. The theory acknowledges the importance of achievement-oriented motivation for choosing specific educational domains, while taking into account the contribution of students' gender roles and stereotypes in this process. The main premise of the theory is that girls' lower academic achievement in STEM, and their lower tendency to choose STEM in secondary and tertiary education courses compared to boys, can be explained by girls' lower self-perceptions of their ability in STEM, by the lower social support for girls to pursue STEM courses, and by the perceived conflict between feminine gender roles and the masculine image of the STEM field. Apart from STEM areas, the theory has often been used in other domains, such as languages and sports (Fredricks \& Eccles, 2005; Gniewosz, Eccles \& Noack, 2015).

More specifically, the theory hypothesises that students' academic achievement and educational choices in a particular domain are influenced by different types of motivation: their expectancy of success, subjective task values, and self-perception of ability in the domain (Eccles et al., 1983). Expectancy of success is defined as the individual's belief in how successful he/she will be in an activity in the future, while ability self-perception (or self-concept of ability) is understood as the individual's evaluations of his/her competence in a given domain. Task values are defined in terms of three components: a) intrinsic value (subjective interest or enjoyment in the activity), b) utility value (usefulness of the task in meeting current or future goals, such as career goals), and c) attainment value (personal importance of doing well in the task) (Eccles \& Wigfield, 2002). Empirical studies based on this theoretical framework have shown that task values are the strongest predictors of educational choices (Eccles et al., 
1983; Updegraff et al., 1996), while expectations of success and students' perceptions of their own abilities are better predictors of academic achievement (Bong, 2001; DeBacker and Nelson, 1999; Greene et al., 1999). However, some studies have shown that both subjective task values and expectations of success are predictors of the intention to study mathematics and physics (Eccles et al., 1985; Simpkins, Davis-Kean \& Eccles, 2006).

The gender dimension of the expectancy-value theory is encapsulated in concepts of gender roles and gender stereotypes regarding school subjects and occupations, which are assumed to influence students' motivation for a specific educational domain. Gender stereotypes are generalised beliefs about typical characteristics of women and men, e.g., about their physical characteristics, personality traits, emotional predispositions, occupational preferences and abilities (Archer \& Lloyd, 2002; Deaux \& LaFrance, 1998). Gender roles are the set of behaviours, traits and interests that are culturally defined as appropriate for one's gender (Galambos, 2004; Lips, 2006) and can be manifested in psychological traits of femininity and masculinity (Deaux \& Lafrance, 1998). Femininity is often operationalised through expressive qualities like being emotional, kind and sympathetic, whereas masculinity is operationalised through instrumental qualities such as being dominant, independent and competitive (Bem, 1974; Spence, Helmreich \& Stapp, 1975). It is expected that stereotypes about mathematics and sciences as male domains can have a negative effect on girls' educational outcomes (academic achievement, and educational choices and intentions) in these domains, especially if they perceive themselves as feminine. According to Eccles (1987), this is because individuals assess the match between their own self-images and possible educational paths and career choices. When the match is not good, e.g., in the case of a girl who perceives herself as feminine and who believes that mathematics and sciences are a masculine domain, it is less likely that the individual will choose these subjects or careers related to him or her.

It was also ussumed that motivation mediates the effect of gender roles on students' educational outcomes, e.g., that masculinity increases and femininity decreases students' motivation to engage in a typically masculine activity, and that motivation further influences their educational outcomes. Empirical studies on gender stereotypes within the expectancy-value model have usually explored stereotypes about the talent or performance of boys and girls in mathematics, sciences or languages (Greene et al., 1999; DeBacker \& Nelson, 1999; Jugović, Baranović, \& Marušić, 2012). Gender roles are usually measured with the Personal Attributes Questionnaire (PAQ, Spence, Helmreich \& Stapp, 1975) or the Bem Sex Role Inventory (BSRI, Bem, 1974) in studies using the 
expectancy-value model. However, the authors of these studies have concluded that the PAQ is probably not an adequate measure of gender roles because its masculinity scale is more likely a measure of self-concept than of gender roles (Eccles, 1981; Eccles et al., 1983), and that the BSRI is an unsuitable measure of gender roles for the adolescent population and does not reflect contemporary notions of masculinity and femininity (DeBacker \& Nelson, 1999). Despite the theoretical elaborations of this part of the expectancy-value model, the role of stereotypes and gender roles has not been sufficiently explored, and results regarding the role of these variables in explaining students' motivation and educational outcomes have not been consistent (e.g., DeBacker \& Nelson, 1999; Greene et al., 1999; Guillet, Sarrazin, Fontayne \& Brustad, 2006). The lack of research examining the impact of gender roles and stereotypes on educational outcomes, the dearth of studies focused specifically on physics (and not only on mathematics or sciences in general) within this model, and the use of gender role measures with questionable validity indicate the need for new research that will take these problems into account.

\section{Research goal}

The goal of the present study was to explore the effects of gender roles, stereotypes and motivation for physics in the explanation of educational outcomes in a stereotypically male educational domain, i.e., academic achievement in physics, intention to choose physics in the matura exam, and intention to choose a technical sciences university course. Eccles and colleagues' expectancy-value model was used as a theoretical framework for the research.

It was hypothesised that:

a) motivation for physics is the strongest predictor of students' academic achievement and educational intentions in a stereotypically male educational domain;

b) endorsing stereotypes about physics or technical sciences occupations as a male domain has a negative effect on girls' (but not boys') academic achievement and educational intentions in a stereotypically male educational domain; and

c) more socially acceptable gender roles for girls (high femininity, low masculinity) have a negative effect on students' academic achievement and educational intentions in a stereotypically male educational domain. 


\section{Methods}

\section{Participants and procedure}

The research sample consisted of 736 third-year general grammar school students from Zagreb, Croatia: 439 girls (59.6\%) and 297 boys (40.4\%). The students had an average age of 17 years.

The questionnaire was administrated in schools during one school hour (45 min). After the purpose of the study, the participants' rights and the confidentiality of the data were explained, the students gave their informed consent and filled in the questionnaires in their classrooms. Participation in the study was voluntary and confidential but not anonymous, because the students' school grades had to be matched with their questionnaires. The students' school grades were obtained from official school documentation at the end of the school year.

\section{Instruments}

The variables that were explored were academic achievement and educational intentions, motivation for physics, gender roles and stereotypes.

\section{Academic achievement and educational intentions}

School grades in physics. Final school grades in physics at the end of the year were obtained from the official school documentation. School grades in Croatia range from 1 (fail) to 5 (excellent).

Intention to choose physics at the state matura exam. Participants were asked: "How likely is it that you will choose physics as your optional subject in the state matura exam?" They could respond using a 5-point Likert-type scale $(1=$ I will certainly not do it, $2=$ I will probably not do it, $3=\mathrm{I}$ am not sure, 4 $=$ I will probably do it, $5=$ I will certainly do it). The state matura exam is used both as a high school leaving exam and as an entry exam to university courses, and physics is typically a required subject for enrolment in technical sciences university courses.

Intention to choose a technical sciences university course. Participants were asked: "How likely is it that you will try to enrol in a university course in technical sciences, e.g., electrical engineering, computer science, mechanical engineering, naval architecture or civil engineering?" The answers were given on a 5 -point Likert-type scale ranging from $1=\mathrm{I}$ will certainly not do it, to $5=$ I will certainly do it. 


\section{Motivation for physics ${ }^{2}$}

The subjective task value of physics was measured with five items about interest (e.g., "How interested are you in learning physics?"), five items about attainment value (e.g., "How important is it to you personally to get good grades in physics?"), and three items about utility value (e.g., "To what extent will what you learn in physics be useful for enrolling in the university course of your choice?"). Responses were positioned on a five-point bipolar scale ( $1=$ not at all, $5=$ fully). Factor analysis revealed an expected three-factor structure with the following factors: $\mathrm{a})$ interest in physics $(\alpha=.85)$, attainment value of physics $(\alpha=.85)$, and utility value of physics $(\alpha=.94)$.

Expectancy of success and perceived competence in physics. Factor analysis revealed two factors: a) perceived competence and expectancy of success in the near future, comprised of five items (e.g., "How successful were you in physics during schooling?"; "How well do you expect to do in the next oral exam in physics?") ( $\alpha=.87$ ), and b) expectancy of success in the distant future, comprised of three items (e.g., "How successful do you think you would be at a university course in which physics knowledge was important?") ( $\alpha=.90)$. Responses were given on a five-point bipolar scale ( $1=$ completely unsuccessful, $5=$ completely successful).

Gender Roles in Adolescence Scale (Jugović \& Kamenov, 2008). Femininity and masculinity were each measured with 16 items about behaviours, traits and interests in different aspects of adolescents' lives, such as family, school, leisure, appearance and intimate relationships. Femininity was operationalised with items about performing traditionally female housework, interest in fashion and cosmetics, taking care of one's own appearance, engaging in typically female sport activities such as aerobics and pilates, and being romantic, sensitive and caring about other people's feelings. Masculinity included items about performing traditionally male housework, interest in sports (especially team sports), interest in cars, caring about looking strong and athletic, taking risks, and being competitive and dominant. Participants assessed how typical each of the behaviours, traits and interests is for them on a 5-point Likert scale ( $1=$ not at all; $5=$ fully). Factor analysis confirmed the expected twofactor structure $\left(\alpha_{\text {Femininity }}=.88 ; \alpha_{\text {Masculinity }}=.84\right)$. Higher scores indicated a more feminine/masculine role.

2 Items for measuring subjective task values, expectancy of success, and perceived competence were modified from studies by Eccles et al. (e.g., Eccles, O’Neill, \& Wigfied, 2005; Eccles \& Wigfield, 1995), and some additional items were included for the purpose of this research (e.g., "Do you like watching TV shows about physics topics?"). 
Gender stereotypes about talent in physics and occupations in technical sciences. Participants were asked to indicate who is more talented for: a) physics, and b) occupations in the domain of technical sciences (e.g., electrical engineering, computer science, mechanical engineering, naval architecture, civil engineering). The answers to the first question were: $1=$ Girls, $2=$ Girls and boys equally, 3 = Boys; and to the second: $1=$ Women, $2=$ Women and men equally, $3=$ Men. The indicator of a gender stereotypical response was the answer Boys/Men.

\section{Results}

\section{Descriptive statistics and gender differences}

Table 1 shows gender differences in educational outcomes, academic motivation in physics and gender roles in adolescence.

Table 1. Gender differences in students' educational outcomes, motivation for physics and gender roles.

\begin{tabular}{|c|c|c|c|c|c|c|c|c|}
\hline \multirow{2}{*}{ Variables } & \multicolumn{2}{|c|}{ Total sample } & \multicolumn{2}{|c|}{ Girls } & \multicolumn{2}{|c|}{ Boys } & \multirow{2}{*}{$\mathrm{t}$} & \multirow{2}{*}{$\mathrm{p}$} \\
\hline & M & SD & M & SD & M & SD & & \\
\hline School grade in physics & 2.90 & 0.99 & 2.98 & 1.01 & 2.78 & 0.96 & 2.597 & .010 \\
\hline $\begin{array}{l}\text { Intention to choose physics in the } \\
\text { state matura exam }\end{array}$ & 1.73 & 1.23 & 1.36 & 0.87 & 2.27 & 1.47 & -9.610 & .001 \\
\hline $\begin{array}{l}\text { Intention to choose a technical } \\
\text { sciences course }\end{array}$ & 2.16 & 1.26 & 1.71 & 1.04 & 2.81 & 1.28 & -12.295 & .001 \\
\hline Interest in physics & 2.33 & 0.94 & 2.11 & 0.84 & 2.64 & 0.98 & -7.641 & .001 \\
\hline Attainment value of physics & 2.97 & 0.95 & 2.91 & 0.92 & 3.06 & 1.00 & -2.115 & .035 \\
\hline Utility value of physics & 2.10 & 1.16 & 1.81 & 0.98 & 2.53 & 1.26 & -8.298 & .001 \\
\hline Perceived competence in physics & 3.11 & 0.74 & 3.06 & 0.73 & 3.20 & 0.75 & -2.518 & .012 \\
\hline $\begin{array}{l}\text { Expectancy of success in the dis- } \\
\text { tant future related to physics }\end{array}$ & 2.36 & 0.99 & 2.12 & 0.87 & 2.73 & 1.03 & -8.410 & .001 \\
\hline Femininity & 3.29 & 0.71 & 3.72 & 0.49 & 2.66 & 0.49 & 27.660 & .001 \\
\hline Masculinity & 3.11 & 0.61 & 2.85 & 0.49 & 3.48 & 0.57 & -15.244 & .001 \\
\hline
\end{tabular}

Note. $M=$ arithmetic mean; $S D=$ standard deviation; $t=\mathrm{t}$-test; $p=$ significance level 
Gender differences were statistically significant in all three educational outcomes. Girls had a higher school grade in physics at the end of the school year, but boys had stronger intentions of choosing physics at the state matura exam, and of enrolling in a technical sciences university course. The average school grade in physics for both boys and girls was " 3 " or "good" $\left(M_{\text {girls }}=\right.$ 2.98, $M_{\text {boys }}=2.78$ ). Girls' higher grades in physics, a subject that is considered as a stereotypically male school subject, are in line with the findings of other Croatian research about girls' higher school grades in the majority of subjects, including physics, mathematics, Croatian and English (Jokić \& Ristić Dedić, 2010; unpublished National Centre for External Evaluation of Education data for 2013/2014). On average, girls responses indicate that they will certainly not choose physics in the matura exam $(M=1.36)$, and that they will probably not choose a technical sciences course $(M=1.71)$, whereas boys state that they will probably not choose physics in the matura exam $(M=2.27)$ and that they are not sure whether they will a choose technical sciences course or not $(M=2.81)$. If their intentions are expressed as percentages, we can see that $23.7 \%$ of boys and only $5 \%$ of girls planned to choose physics in the matura exam, whereas $33.6 \%$ of boys and $7.1 \%$ of girls planned to choose technical sciences course. Boys were also more interested in physics; they valued success in physics more than girls, and they perceived physics as more useful for them than girls did. In addition, boys perceived their own competencies in physics more positively and had higher expectancy of success in physics in the future than girls, despite the fact that they had lower school grades in physics. One of the explanations for girls' lower ability self-perception and lower expectations of success in physics is their lower self-esteem in adolescence compared to boys; they have a more critical attitude towards their own abilities and achievements, especially in a stereotypically male domain (Bleidom, 2016; Feingold, 1994). As expected, boys and girls differed in gender roles: boys had higher results on the masculinity scale and girls on the femininity scale. The different gender roles of girls and boys could explain girls' higher academic achievement compared to boys. Studies of the construction of femininity show that striving for and achieving high academic success are aspects of girls' femininity. At the same time, however, many girls find it hard to speak confidently about their academic successes, and feel the need to minimise the importance of their achievements (Renold, 2001; Renold \& Allan, 2004; Walkerdine, Lucey, \& Melody, 2001). In addition, research on masculinity shows that a lack of (apparent) effort invested in learning and school work is an important aspect of masculinity among young men (Jackson, 2002; Jackson \& Dempster, 2009; Morris, 2008), which can result in lower academic achievement (Kessels \& Steinmayr, 2013). 
Table 2. Acceptance of gender stereotypes about talent in physics and occupations in technical engineering.

\begin{tabular}{|c|c|c|c|c|c|c|c|c|}
\hline \multirow{2}{*}{ Stereotypes } & \multicolumn{2}{|c|}{$\begin{array}{c}\text { Total } \\
\text { sample }\end{array}$} & \multicolumn{2}{|c|}{ Girls } & \multicolumn{2}{|c|}{ Boys } & \multirow{2}{*}{$\chi^{2}$} & \multirow[t]{2}{*}{$p$} \\
\hline & $f$ & $\%$ & $f$ & $\%$ & $f$ & $\%$ & & \\
\hline $\begin{array}{l}\text { Stereotypes about boys being more } \\
\text { talented in physics }\end{array}$ & 394 & 53.5 & 214 & 48.7 & 180 & 60.6 & 10.015 & .001 \\
\hline $\begin{array}{l}\text { Stereotypes about men being more } \\
\text { talented for occupations in technical } \\
\text { engineering }\end{array}$ & 567 & 77.0 & 324 & 73.8 & 243 & 81.8 & 6.432 & .007 \\
\hline
\end{tabular}

Note. $f=$ frequency; $\%$ = percentage of participants that accept stereotypes; $\chi^{2}=$ chi-square test; $p=$ significance level

Over half of the participants thought that boys are more talented in physics $(53.5 \%)$, and over three quarters (77\%) believed that men are more talented for occupations in the technical sciences domain (Table 2). However, there were gender differences in the endorsement of these stereotypes, with boys being more inclined to believe that members of their own gender are more talented in these domains. These findings are not surprising given that previous studies have shown that natural sciences and technology are considered a male domain (Francis et al., 2017; Nosek, Banaji \& Greenwald, 2002), and that young men are more likely to accept stereotypes about the superiority of men and boys in these domains (Brandella \& Staberg, 2008; Hyde et al., 1990).

\section{Predictors that explain school grades in physics and intentions to choose physics and a technical sciences course}

In order to explore the predictors of school grades in physics and intentions to choose physics in the matura exam and a technical sciences course, hierarchical regression analyses were conducted. Correlations between all of the criterion variables and predictors were examined, followed by hierarchical regression analyses, conducted separately for each gender. 


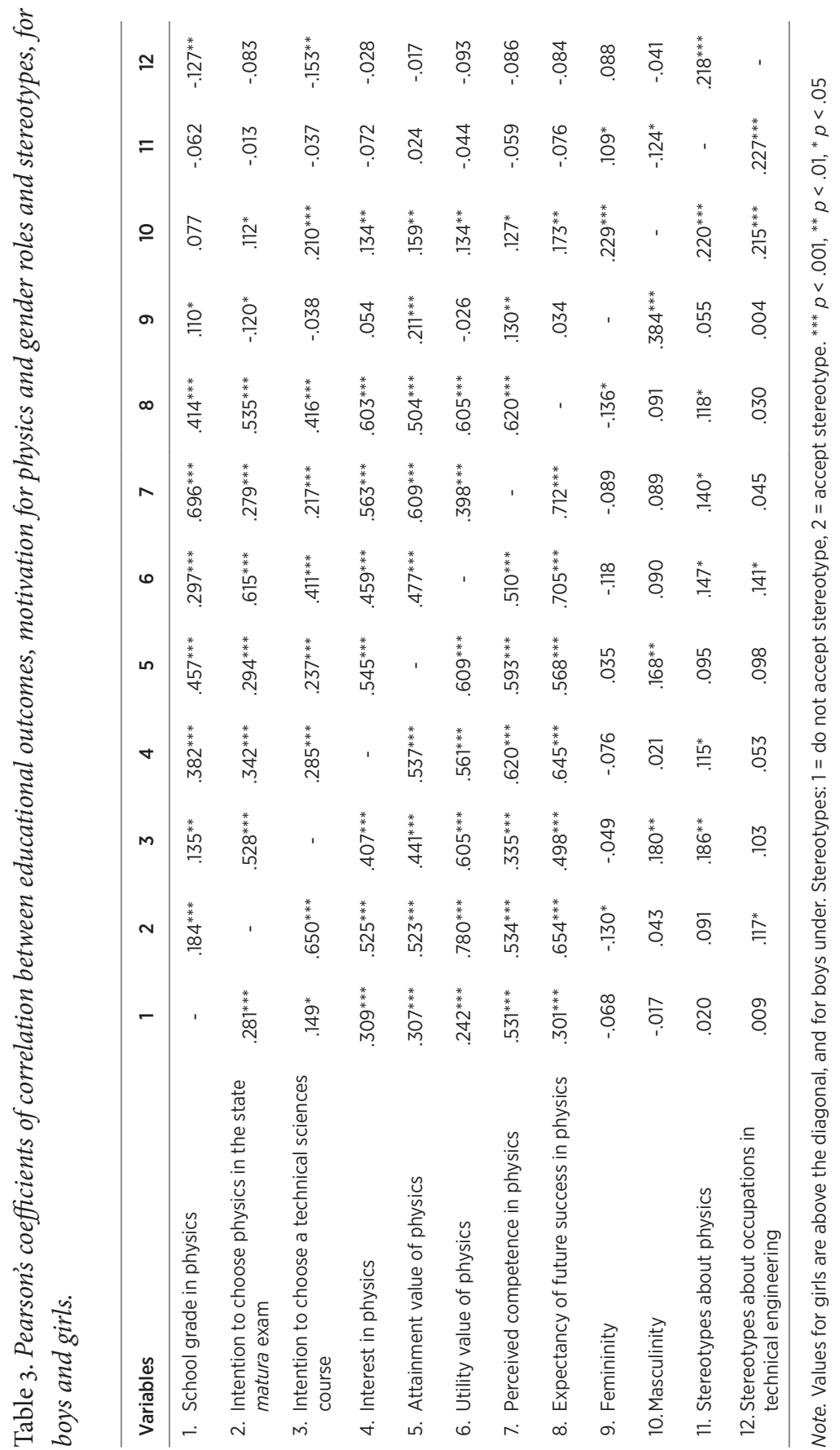


As Table 3 shows, school grades in physics had the highest and positive correlation with perceived competence in physics for both boys and girls. Intentions to choose physics and intentions to choose a technical sciences course had the highest (positive) correlations with the utility value of physics and the expectancy of future success in physics, again for both boys and girls. Gender roles and stereotypes had lower correlations with educational outcomes than academic motivation, and some of their correlations were not statistically significant. For both genders, masculinity was positively related to the choice of a technical sciences course and femininity negatively to the choice of physics. Stereotypes were negatively related to some of the girls' educational outcomes and positively to some of the boys' educational outcomes. 


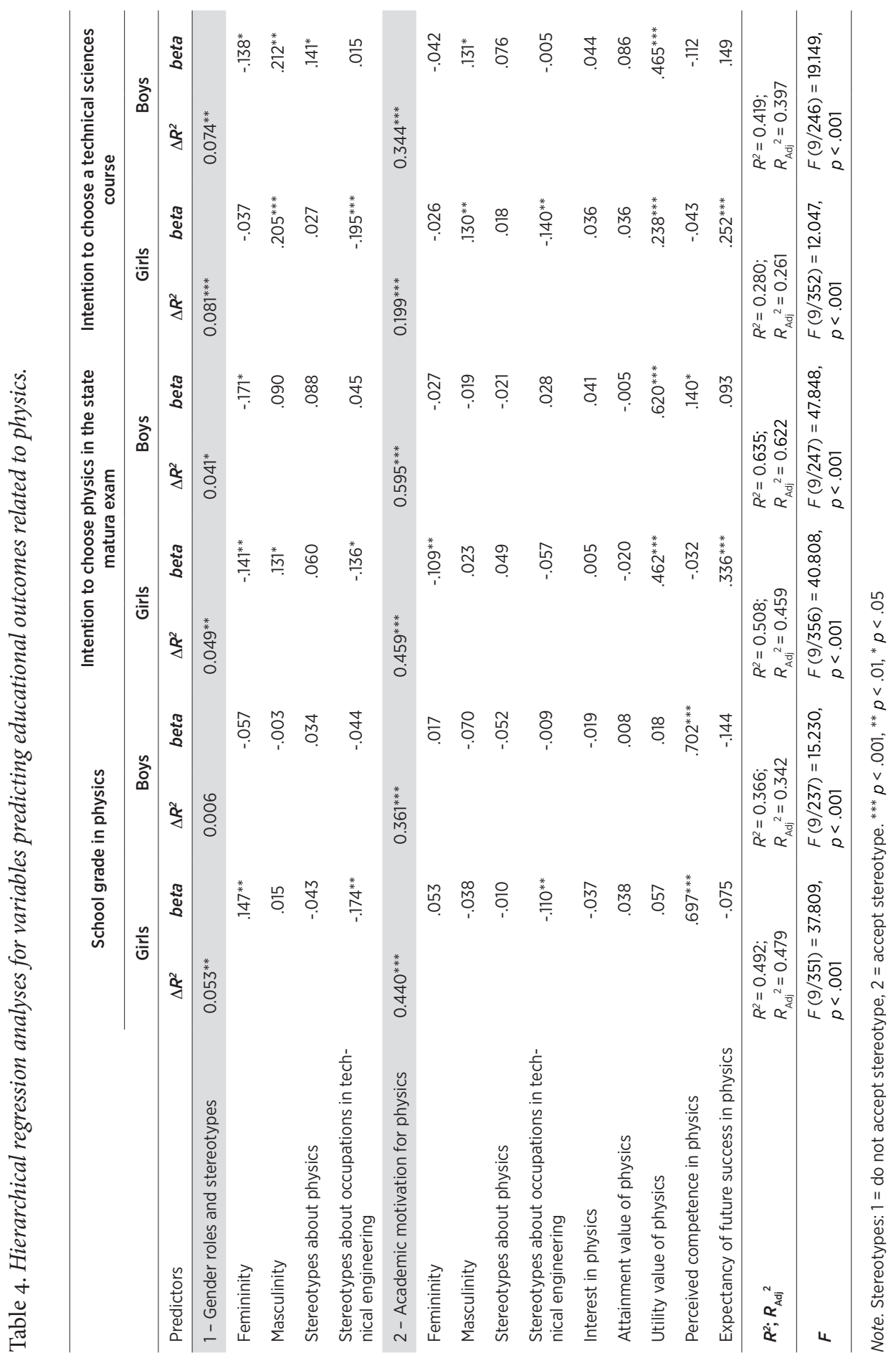


Hierarchical regression analyses were conducted in two steps, separately for each gender group. The first block of variables included gender roles and stereotypes, and the second block included motivation for physics. The chosen predictors explained $47.9 \%(p<.001)$ of the total variance of the school grades in physics for girls, and $34.2 \%(p<.001)$ for boys (Table 4$)$. The first block, containing gender roles and stereotypes, explained $5.3 \%(p<.01)$ of the variance of girls' grades in physics, whereas it did not significantly contribute to the explanation of boys' physics grades. The block with motivational variables additionally explained $44.0 \%(p<.001)$ of the variance in the female sample and $36.1 \%$ $(p<.001)$ in the male sample. These results show that more predictors were significant in explaining girls' school grades than boys'. In the first step of the regression analysis, no variable proved to be a significant predictor of the boys' school grades in physics, and in the second step, only perceived competence in physics was significant. On the other hand, femininity (positively) and stereotypes about technical sciences occupations (negatively) predicted grades in physics in the female sample. In the second step, after introducing motivation for physics, femininity lost its significance, whereas perceived competence became a significant (and the strongest) predictor of girls' school grades in physics, along with stereotypes. These results imply a possible mediating role of perceived competence in physics in the effect that femininity had on girls' grades in physics, given that femininity was correlated with perceived competence and school grades in physics, and that femininity lost its significance after adding perceived competence to the analysis. To conclude, the results of the last step of the regression analysis show that believing in one's own competence in physics contributed to higher physics grades for both genders, and that rejecting stereotypes about men's greater talent in technical sciences occupations contributed to higher physics grades only for girls. The hypothesis about motivation as a key predictor was confirmed, given that ability self-perception was the strongest predictor of school grades in physics. The second hypothesis about the negative effect of stereotypes on girls' (but not boys') academic achievement in a male-dominated field was also supported by the data. Contrary to the third hypothesis, girls with a stereotypically female gender role (higher femininity) had higher grades in physics.

The same predictors explained $49.5 \%(p<.001)$ of the total variance of girls' intentions and $62.2 \%(p<.001)$ of boys' intentions to choose physics in the matura exam (Table 4 ). Gender roles and stereotypes explained a similar amount of variance of girls' $(4.9 \%, p<.01)$ and boys' intentions to choose physics $(4.1 \%, p<.05)$, whereas motivational variables contributed more to the explanation of boys' intentions $(59.5 \%, p<.001)$ than girls' $(45.9 \%, p<.001)$. 
However, fewer predictors contributed to the explanation of boys' intentions than girls' intentions. More specifically, only femininity was found to be a significant predictor of the boys' intentions in the first step, whereas perceived competence and utility value (which was the strongest predictor), significantly contributed to the explanation of boys' intentions in the second step. The results of the first step on the female sample show that lower femininity scores, higher masculinity scores, and rejection of stereotypes about men's greater talent in technical sciences occupations contributed to their stronger intentions of choosing physics. In the second step on the female sample, masculinity and stereotype lost their significance. Besides femininity, other significant predictors of girls' intentions were expectancy of future success in physics and the utility value of physics, which was also the strongest predictor, as in the male sample. Self-concept of physics ability contributed to boys' stronger intentions to choose physics, whereas lower femininity and higher expectancy of future success in physics contributed to girls' stronger intentions. The first hypothesis was confirmed by these analyses, given that perceived usefulness was the strongest predictor of the intention to choose physics, for both girls and boys. The second hypothesis was also confirmed, but only in the first step: girls who endorsed stereotypes about technical sciences occupations as a male domain were less likely to choose physics, whereas stereotypes were not important for boys. The third hypothesis about the positive effect of a stereotypically female gender role on the intention to choose physics was confirmed for both genders in the first step, and for girls in the second step.

Finally, the results of the regression analyses for the explanation of the intention to choose a technical sciences course show that more variance was explained on the sample of boys $(39.7 \%, p<.001)$ than girls $(26.1 \%, p<.001)$ (Table 4 ). This is largely due to the role of motivation, which explained more additional variance on the male sample $(34.4 \%, p<.001)$ than the female sample $(19.9 \%, p<.001)$. Gender roles and stereotypes explained a similar amount of variance of girls' $(8.1 \%, p<.01)$ and boys' intentions $(7.4 \%, p<.05)$ to choose a technical sciences course. Masculinity (positively) and stereotypes about technical sciences occupations (negatively) predicted girls' intentions to choose a technical sciences course in the first step. In the second step, these predictors remained significant, and the utility value and expectancy of future success in physics contributed to these intentions, as well. On the male sample, lower femininity, higher masculinity and acceptance of stereotypes about men's greater talent in physics contributed to stronger intentions to choose a technical sciences course (in the first step). In the second step, masculinity and the utility value of physics contributed to boys' stronger intentions. A comparison of the 
results reveals that, for both boys and girls, higher masculinity self-perceptions and utility value of physics contributed to a greater likelihood of choosing a technical sciences course. In addition, rejecting stereotypes about men's greater talent in technical sciences occupations, and holding high expectations of one's own future success in physics additionally contributed to girls' stronger intentions. Given that motivational variables were the strongest predictors, the first hypothesis was confirmed. The second hypothesis about the negative effect of stereotypes on girls' choice of a typically male domain was confirmed, but in addition, stereotypes had a positive effect on boys' choice in the first step. As expected, stereotypically female gender roles (lower masculinity) had a negative effect on girls as well as boys' educational intentions in a male-dominated field.

\section{Discussion and conclusion}

The goal of the research was to explore predictors of academic achievement and educational intentions in a male-dominated field: physics. Motivation for physics had the most important role in explaining these educational outcomes, thus confirming the first hypothesis. More precisely, self-concept of physics ability had the key role in predicting school grades in physics for both genders. This is in line with previous studies concerning the greater contribution of ability self-perceptions or expectancy of success (compared to subjective task values) in predicting academic achievement (e.g., Bong, 2001; DeBacker \& Nelson, 1999; Greene et al., 1999). Key predictors of educational intentions in physics and the technical sciences domain were the utility value of physics for boys, and utility value and expectancy of future success in physics for girls. This is in line with previous studies, which have shown that subjective task values are the strongest predictors of educational choices (e.g., Eccles et al., 1983; Updegraff et al., 1996).

Gender roles and stereotypes also contributed to the explanation of the variance of these educational outcomes, although to a lesser extent than motivation for physics. Higher endorsement of masculinity predicted girls' and boys' stronger intentions to choose a technical sciences course for both genders, and weaker endorsement of femininity predicted girls' stronger intention to choose physics in the matura exam. These findings might imply that endorsement of a socially expected boys' gender role is a preferable role for the choice of a stereotypically male educational or career domain. The findings can be explained by the expectancy-value model (Eccles et al., 1983), according to which the conflict between a feminine gender role and the educational choice of a stereotypically male domain is responsible for girls' weaker intentions to 
choose that educational domain. An additional explanation of the findings can be found in poststructuralist theories about gender as performative (Butler, 1990). Paechter (2001), for example, described how adolescent girls and boys confirm their femininity or masculinity by exaggerated performance of gender roles. Thus, it can be assumed that adolescents confirm their gender roles by choosing activities or educational paths that are expected of their gender, or by refraining from choosing them, as can be seen in girls' underrepresentation in physics and technical sciences. Comparison of the results of previous American studies and the present Croatian study of the effects of gender roles on educational outcomes reveals that gender roles were less important in the explanation of educational outcomes on American samples (Eccles et al., 1985; DeBacker \& Nelson, 1999; Greene et al., 1999). One of the reasons for this difference could be more traditional gender roles in Croatia than in the US (Frieze, Ferligoj, Kogošvek, Rener, Horvat \& Šarlija, 2003), and possibly stronger socialisation of children and adolescents in more gender-typical behaviours, traits and interests in Croatian society, which further leads to gendered educational outcomes. The other explanation could be the validity of the gender-role scales used in these studies. The US studies use scales that either measure outdated notions of gender roles, scales that do not measure gender roles but expressivity and instrumentality, and scales that were not intended for the adolescent population, such as the Bem Sex Role Inventory (Bem, 1974), and the Personal Attributes Questionnaire (Spence, Helmreich \& Stapp, 1975). The present Croatian research, on the other hand, employed a new scale for measuring gender roles specifically for adolescents, which reflects contemporary notions of femininity and masculinity in different domains of adolescent lives (and not just expressivity and instrumentality) (Gender Roles in Adolescence Scale, Jugović \& Kamenov, 2008).

Endorsing stereotypes about technical sciences occupations predicted girls' lower grades in physics and lower intention to choose a technical sciences university course, which confirms the hypothesis proposed by the expectancyvalue theory (Eccles et al., 1983). These findings can also be explained with the stereotype threat theory (Steele, 1997). For example, research shows that activation of negative stereotypes, such as stereotypes about women's lower abilities or weaker talent in mathematics or physics, can decrease their achievement and interest in choosing occupations in these domains (Davies et al., 2002; Inzlicht \& Ben-Zeev, 2003; Marchand \& Taasoobshirazi, 2013; Schmader \& Johns, 2003; Smith \& White, 2002). Although stereotypes did not significantly contribute to the explanation of boys' educational outcomes in the last step of the regression analyses in the present research, stereotypes about boys' greater talent in physics did have a positive effect on their intention to choose a technical sciences 
course in the first step of the regression analysis. This is in line with research findings demonstrating that stereotypes about one's own group can have a positive effect on academic achievement (e.g., Ambady, Shih, Kim, \& Pittinsky, 2001).

The results of the regression analyses also show that there is a wider range of statistically significant predictors on the female sample than on the male sample. It seems that, for boys to choose physics or technical courses, it is enough just to perceive physics as useful, whereas there are more requirements that have to be met for girls: they need to perceive physics as useful, but they also need to expect to be successful in a university course or occupation related to physics, to reject stereotypes in which most students believe, and to endorse a stereotypically male gender role. In addition, although girls have better academic achievement in physics than boys, they underestimate their abilities and the likelihood of their success in physics. Furthermore, girls' underrated ideas of their capabilities affect their educational intentions. Although these findings imply that girls need more support to choose a male-dominated field than boys, studies show that parents have more doubts in their daughters' abilities in a typically male domain (Tenenbaum \& Leaper, 2003) and that girls receive less encouragement when choosing a stereotypically male educational domain (Baranović \& Jugović, 2011; Mujtaba \& Reiss, 2013).

The chosen predictors explained the most variance regarding the intention to choose physics in the matura exam, whereas the intention to choose a technical sciences course was the least explained on the female sample and physics grade on the male sample. It therefore seems that some other factors could also be relevant for the latter two educational outcomes. For example, previous studies have shown that boys have more negative attitudes towards learning and school than girls (Jarvis \& Pell, 2002; Lupart, Cannon, \& Telfer, 2004; Verešová \& Malá, 2016). The importance of having children, bearing in mind balancing family life and work obligations, as well as the possibility of being discriminated against in a male-dominated working environment are important in explaining why women are less likely to decide for a career in a maledominated field (Curry, Trew, Turner, \& Hunter, 1994; Frome, Alfred, Eccles, \& Barber, 2006; Steele, James, \& Barnett, 2002). It is therefore fair to assume that attitudes towards learning and school could additionally explain boys' lower academic achievement, whereas perceived family obligations and possible gender discrimination in the workplace could additionally explain girls' hesitation to choose technical sciences.

One possible limitation of the present study was its correlational design, which does not enable a causal conclusion. Another limitation is that 
only educational intentions were measured, and not actual educational choices. Therefore, a longitudinal design would be more suitable in order to explore the influence of gender roles, stereotypes and motivation on academic achievement and actual educational choices (not just intentions). There is also the question of whether our results, which were obtained on a sample of general grammar schools from Zagreb, can be generalised to a wider population of students from different types of schools and locations. Finally, it is important to point out that, although these results can be generalised to other typically male domains, there is a need to explore factors that are relevant for the choice of a stereotypically female domain, so that the underrepresentation of men in teaching, nursing, etc. is also addressed.

Analyses of policies regarding gender inequalities in education in different EU countries have shown that their most common goal is to overcome traditional gender roles and stereotypes, by either gender-sensitive career guidance, gender-sensitive teaching, or revisions of curricula (Eurydice, 2010). Similarly, one of the goals of the Croatian National Policy for Gender Equality 2011-2015 (Office for Gender Equality of the Government of the Republic of Croatia, 2011) was to achieve gender balance in educational choices in secondary schools and in higher education. The measure employed to achieve this goal was to develop a gender-sensitive programme of career guidance for students in their final year of primary schooling, in order to encourage female students' interest in enrolling in secondary schools where male students are predominant, and vice versa. However, the problem with this measure is that it focuses on students in their final years of schooling, when their stereotypical images of educational and career fields are already formed. The other limitation is that the activities conducted (e.g., organising Job Fairs and providing brochures that contain descriptions of occupations) did not necessarily include all students, but only those who were the most interested. Furthermore, they did not specifically focus on students' misperceptions regarding the gender dimension of career choices. It would therefore be more useful to start organising activities aimed at achieving gender balance in educational choices in early primary school, and not at the end of primary or secondary school (when gender stereotypes are already formed). It would also be useful to specifically focus on deconstructing gender stereotypes and traditional gender roles that restrain students from choosing gender non-stereotypical careers, despite their real interests and abilities. 


\section{References}

Ambady, N., Shih, M., Kim, A., \& Pittinsky, T. L. (2001). Stereotype susceptibility in children: Effects of identity activation on quantitative performance. Psychological Science, 12(5), 385-391.

Archer, J., \& Lloyd, B. (2002). Sex and gender (2nd ed.). New York: Cambridge University Press. Archer, J., \& Freedman, S. (1989). Gender stereotypic perceptions of academic disciplines. British Journal of Educational Psychology, 59, 306-313.

Bem, S. L. (1974). The measurement of psychological androgyny. Journal of Consulting and Clinical Psychology, 42(2), 155-162.

Bettio, F., \& Verashchagina, A. (2009). Gender segregation in the labour market. Root causes, implications and policy responses in the EU. Report by the European Commission's Expert Group on Gender and Employment Issues, European Communities. Luxembourg: Publications Office of the European Union.

Bleidom, W., Denissen, J. J. A., Gebauer, J. E., Arslan, R. C., Rentfrow, P. J., Potter, J., \& Gosling, S. D. (2016). Age and Gender Differences in Self-Esteem - A Cross-Cultural Window. Journal of Personality \& Social Psychology, 111(3), 396-410.

Blickenstaff, J. C. (2005). Women and science careers: leaky pipeline or gender filter? Gender and Education, 17(4), 369-386.

Bong, M. (2001). Role of self-efficacy and task-value in predicting college students' course performance and future enrollment intentions. Contemporary Educational Psychology, 26(4), 553-570. Brandella, G., \& Staberg, E. (2008). Mathematics: a female, male or gender-neutral domain? A study of attitudes among students at secondary level. Gender and Education, 20(5), 495-509.

Breakwell, G. M., Vignoles, V. L., \& Robertson, T. (2003). Stereotypes and crossed category evaluations: The case of gender and science education. British Journal of Psychology, 94(4), 437-455. Croatian Bureau of Statistics (2015). Women and men in Croatia.

Curry, C., Trew, K., Turner, I., \& Hunter, J. (1994). The effect of life domains on girls' possible selves.

Adolescence, 29(113), 133-150.

Davies, P. G., Spencer, S. J., Quinn, D. M., \& Gerhardstein, R. (2002). Consuming images:

How television commercials that elicit stereotype threat can restrain women academically and professionally. Personality and Social Psychology Bulletin, 28(12), 1615-1628.

Deaux, K., \& LaFrance, M. (1998). Gender. In D. T. Gilbert, S. T. Fiske, \& G. Lindzey (Eds.), The Handbook of Social Psychology (4th ed.) (vol. 1, pp. 788-827). Boston: McGraw-Hill.

DeBacker, T. K. \& Nelson, R. M. (1999). Variations on an expectancy-value model of motivation in science. Contemporary Educational Psychology, 24(2), 71-94.

Eccles, J. (1987). Gender roles and women's achievement-related decisions. Psychology of Women Quarterly, 11(2), 135-172.

Eccles-Parsons, J. (1981). Sex stereotyping versus perceived value as the mediator of sex differentiated math participation. Paper presented at the meeting of the Society for Research in Child Development, Boston, MA. 
Eccles, J. S., Adler, T. F., Futterman, R., Goff, S. B., Kaczala, C. M., Meece, J. L., \& Midgley, C. (1983). Expectancies, values and academic behaviors. In J. T. Spence (Ed.), Achievement and achievement motives. San Francisco: W. H. Freemen.

Eccles, J. S., Adler, T. F., Futterman, R., Goff, S. B., Kaczala, C. M., Meece, J. L., \& Midgley, C. (1985). Self-perceptions, task perceptions, socializing influences, and the decision to enroll in mathematics, In S. F. Chipman, L. R. Brush \& D. M. Wilson (Eds.). Women and Mathematics: Balancing the Equation (pp. 95-121), Hillsdale, NJ: Erlbaum.

Eccels, J. S., O’Neill, S.A., \& Wigfield, A. (2005). Ability self-perceptions and subject task values in adolescents and children. In K. A. Moore \& L. H. Lippman (Eds) What do children need to flourish? Conceptualizing and measuring indicators of positive development (pp. 237-249). New York, NY:

Springer.

Eccles, J. S., \& Wigfield, A. (1995). In the mind of the actor: The structure of adolescents' academic achievement related-beliefs and self-perceptions. Personality and Social Psychology Bulletin, 21(3), $215-225$.

Eccles, J. S., \& Wigfield, A. (2002). Motivational beliefs, values, and goals. Annual Review of Psychology, 53(1), 109-132.

European Commission (2014). Report on equality between women and men.

Eurydice (2010). Gender differences in educational outcomes: Study on the measures taken and the current situation in Europe. Brussels: Eurydice. Education, Audiovisual and Culture Executive Agency. Retrieved from http://www.eurydice.org.

Feingold, A. (1994). Gender differences in personality: A meta-analysis. Psychological Bulletin, 116(3), $429-456$.

Francis, F., Archer, L., Moote, J., DeWitt, J., MacLeod, E., \& Yeomans, L. (2017). The Construction of Physics as a Quintessentially Masculine Subject: Young People’s Perceptions of Gender Issues in Access to Physics. Sex Roles, 76(3), 156-174.

Fredricks, J. A., \& Eccles, J. S. (2005). Family socialization, gender, and sport motivation and involvement. Journal of Sport and Exercise Psychology, 27(1), 3-31.

Frieze, I. H., Ferligoj, A., Kogošvek, T., Rener, T., Horvat, J., \& Šarlija, N. (2003). Gender-role attitudes in university students in the United States, Slovenia, and Croatia. Psychology of Women Quarterly, 27(3), 256-261.

Frome, P. M., Alfeld, C. J., Eccles, J. S., \& Barber, B. L. (2006). Why don't they want a male-dominated job? An investigation of young women who changed their occupational aspirations. Educational Research and Evaluation, 12(4), 359-372.

Galambos, N. L. (2004). Gender and gender role development in adolescence. In R. M. Lerner \& L. Steinberg (Eds.), Handbook of adolescent psychology (2nd ed.) (pp. 233-262). New York: Wiley. Gniewosz, B., Eccles, J. S., \& Noack, P. (2015). Early Adolescents' Development of Academic Self-Concept and Intrinsic Task Value: The Role of Contextual Feedback. Journal for Research on Adolescence, 25(3), 459-473.

Gonsalves, A. (2014). "Physics and the girly girl - there is a contradiction somewhere": Doctoral 
students' positioning around discourses of gender and competence in physics. Cultural Studies in Science Education, 9(2), 503-521.

Greene, B. A., DeBacker, T. K., Ravindran, B., \& Krows, A. J. (1999). Goals, values, and beliefs as predictors of achievement and effort in high school mathematics classes. Sex Roles, 40(5/6), 421-458. Grimshaw, D., \& Rubery, J. (2007). 'Undervaluing women's work'. European Work and Employment Research Centre, University of Manchester, Working Paper Series, No 53, Equal Opportunities Commission.

Guillet, E., Sarrazin, P., Fontayne, P., \& Brustad, R. J. (2006). Understanding female sport attrition in a stereotypical male sport within the framework of Eccles's expectancy-value model. Psychology of Women Quarterly, 3o(4), 358-368.

Herrmann, S.D., Adelman, R. M., Bodford, J. E., Graudejus, O., Okun, M.A., Kwan, V. S. Y. (2016). The Effects of a Female Role Model on Academic Performance and Persistence of Women in STEM Courses. Basic \& Applied Social Psychology, 38(5), 258-268.

Hyde, J. S., Fennema, E., Ryan, M., Frost, L. A., \& Hopp, C. (1990). Gender comparisons of mathematics attitudes and affect: a meta-analysis. Psychology of Women Quarterly, 14(3), 299-324. Inzlicht, M., \& Ben-Zeev, T. (2003). Do high-achieving female students underperform in private? The implications of threatening environments on intellectual processing. Journal of Educational Psychology, 95(4), 796-805.

Jackson, C. (2002). 'Laddishness' as a self-worth protection strategy. Gender and Education, 14(1), $37-50$.

Jackson, C., \& Dempster, S. (2009). 'I sat back on my computer...with a bottle of whisky next to me': Constructing 'cool' masculinity through 'effortless' achievement in secondary and higher education. Journal of Gender Studies, 18(4), 341-356.

Jacobs, J. E., Lanza, S., Osgood, W. D., Eccles, J. S., \& Wigfield, A. (2002). Changes in children's self-competence and values: Gender and domain differences across grades one through twelve. Child Development, 73(2), 509-527.

Jarvis, T., \& Pell, A. (2002) Changes in primary boys' and girls' attitudes to school and science during a two-year science in-service programme. The Curriculum Journal, 13(1), 43-69.

Jugović, I. (2010). Uloga motivacije i rodnih stereotipa u objašnjenju namjere odabira studija u stereotipno muškom području [The role of motivation and gender stereotypes in explanation of the intention of a study choice in stereotypically male domain]. Sociologija i prostor, 186(1), 77-98. Jugović, I., Baranović, B., \& Marušić, I. (2012). Uloga rodnih stereotipa i motivacije u objašnjenju matematičkog uspjeha i straha od matematike [The role of gender stereotypes and motivation in the explanation of mathematics achievement and anxiety]. Suvremena psihologija, 15(1), 65-79. Jugović, I., \& Kamenov, Ž. (2008). Razvoj instrumenta za ispitivanje rodnih uloga u adolescenciji [The development of an instrument for measuring gender roles in adolescence]. Suvremena psihologija, 11(1), 93-106.

Kessels, U., \& Steinmayr, R. (2013). Macho-man in school: Toward the role of gender role selfconcepts and help seeking in school performance. Learning and Individual Differences, 23, 234-240. 
Lips, H. M. (2006). A New Psychology of Women: Gender, Culture, and Ethnicity (3rd ed.). New York: McGraw-Hill.

Lupart, J. L., Cannonb, E., \& Telfer, J. A. (2004). Gender differences in adolescent academic achievement, interests, values and life-role expectations. High Ability Studies, 15(1), 25-42.

Marchand, G. C., \& Taasoobshirazi, G. (2013). Stereotype Threat and Women's Performance in Physics. International Journal of Science Education, 35(18), 3050-3061.

Marušić, I. (2006). Motivacija i školski predmeti: spolne razlike među učenicima u kontekstu teorije vrijednosti i očekivanja [Motivation and school subjects: gender differences in the context of expectancy-value theory]. In B. Baranović (Ed.), Nacionalni kurikulum za obvezno obrazovanje u Hrvatskoj - različite perspektive [National Curriculum for Compulsory Education in Croatia: Different Perspectives] (pp. 219-257). Zagreb: Institut za društvena istraživanja.

Morris, E. W. (2008). "Rednecks," "rutters," and rithmetic: Social class, masculinity, and schooling in a rural context. Gender and Society, 22(6), 728-751.

Mujtaba, T., \& Reiss, M. J. (2012). Gender differences in 15 year-olds' perceptions of physics, physics teachers and physics lessons. In C. Bruguière, A. Tiberghien, \& P. Clément. (Eds.), E-Book Proceedings of the ESERA 2011 Conference: Science Learning and Citizenship (pp. 27-33). Retrieved from http://lsg.ucy.ac.cy/esera/e_book/base/ebook/ebook-esera2o11.pdf.

Mujtaba, T., \& Reiss, M. J. (2013). What sort of girl wants to study physics after the age of 16 ? Findings from a large-scale UK survey. International Journal of Science Education, 35(17), 2979-2998. Murphy, P., \& Whitelegg, E. (2006). Girls in the physics classroom: A review of the research into the participation of girls in physics. London: Institute of Physics.

National Science Foundation, National Center for Science and Engineering Statistics (2015). Women, Minorities, and Persons with Disabilities in Science and Engineering: 2015. Special Report NSF 15-311. Arlington, VA. Retrieved from http://www.nsf.gov/statistics/wmpd/.

Nosek, B., Banaji, M., \& Greenwald, A. (2002). Math = male, me = female, therefore math not-equalto me. Journal of Personality and Social Psychology, 83(1), 44-59.

Office for Gender Equality of the Government of the Republic of Croatia (2011). National Policy for Gender Equality 2011-2015. Zagreb.

Paechter, C. (2001). Using poststructuralist ideas in gender theory and research. In B. Francis

\& C. Skelton (Eds.), Investigating gender. Contemporary perspectives in education. Buckingham, Philadelphia: Open University Press.

Renold, E. (2001). 'Square-girls', Femininity and the Negotiation of Academic Success in the Primary School. British Educational Research Journal, 27(5), 577-588.

Renold, E., \& Allan, A. (2004). Bright and beautiful: high achieving girls and the negotiation of young 'girlie' femininities. Paper presented at British Educational Research Association Annual Conference, 16-18 September, UMIST, Manchester, UK.

Schmader, T., \& Johns, M. (2003). Converging evidence that stereotype threat reduces working memory capacity. Journal of Personality and Social Psychology, 85(3), 440-452.

Simpkins, S. D., Davis-Kean, P.E., \& Eccles, J. S. (2006). Math and science motivation: A longitudinal 
examination in the links between choices and beliefs. Developmental Psychology, 42(1), 70-83. Smith, J. L., \& White, P. H. (2002). An examination of implicitly activated, explicitly activated, and nullified stereotypes on mathematical performance: It's not just a woman's issue. Sex Roles, $47(3)$, 179-191.

Spence, J. T., Helmreich, R., \& Stapp, J. (1975). Ratings of self and peers on the sex role attributes and their relation to self-esteem and conceptions of masculinity and femininity. Journal of Personality and Social Psychology, 32(1), 29-39.

Steele, C. M. (1997). A threat in the air: How stereotypes shape the intellectual identities and performance. American Psychologist, 52(6), 613-629.

Steele, J., James, J. B., \& Barnett, R. C. (2002). Learning in a man's world: Examining the perceptions of undergraduate women in male-dominated academic areas. Psychology of Women Quarterly, 26(1), 46-50.

Stewart, M. (1998). Gender issues in physics education. Educational Research, 40(3), 283-293. Tenenbaum, H. R., \& Leaper. C. (2003). Parent-child conversations about science: The socialization of gender inequities? Developmental Psychology, 39(1), 34-47.

Updegraff, K. A., Eccles, J. S., Barber, B. L., \& O’Brien, K. M. (1996). Course enrollment as selfregulatory behavior: Who takes optional high school math courses? Learning and Individual Differences, 8(3), 239-259.

Walkerdine., V., Lucey, H., \& Melody, J. (2001). Growing up girl: Psychosocial explorations of gender and class. Basingstoke: Palgrave.

\section{Biographical note}

Ivana Jugović, $\mathrm{PhD}$, is a Research Associate at the Institute for Social Research in Zagreb (Croatia) - Centre for Educational Research and Development. She holds a $\mathrm{PhD}$ in psychology from the Faculty of Humanities and Social Sciences, University of Zagreb (Croatia). Her expertise is in educational psychology and gender equality, with a specific focus on gender issues in education. She was engaged as a researcher in projects exploring gender stereotypes in textbooks, gendered educational and career choices, teacher professional development, gender based violence in schools, and gender inequality in education and family. She collaborates with national stakeholders in educational and gender equality area, advocating for the implementation of gender-sensitive policies in education. 